\author{
Wojciech Sajkowski \\ Faculty of History \\ Adam Mickiewicz University, Poznań \\ wojciech.sajkowski@amu.edu.pl
}

\title{
Neighbourhood of the City and the Provinces in Dalmatia in the Light of Chosen Examples of Early Modern French Travel Literature
}

\begin{abstract}
In early modern period, Dalmatia was a region which was culturally diversified. Such cities as Zadar or Split were centres of Italian culture, while the provinces were a part of the Slavic world. Their location on the route to Turkey made them a frequent stop for French travellers, including (1675) or Louis-François Cassas (1782), whose testimonies became a basis for printed publications. In their testimonies, readers could find information about Dalmatian cities and provinces, and the differences between then. The latter issue is an important, yet often neglected addition to the discussion on the shaping of the image of the Balkans.

In this study, I concentrate on this French approach to this problem, because it can be considered as representative for other Western European perspectives. The French look at the issue of neighbourhood of the city and the provinces was characterized by a distance, which is rarely found in Venetian sources. The wide chronologic scope of the study will allow to show changes which occurred in the French image of Dalmatia during the age of Enlightenment.

The paper tries to analyse the travel literature focusing on how it portrays the neighbourhood of the city and the provinces in Dalmatia and demonstrates that this image combined two perspectives. The first related to the neighbourhood of the sophisticated Italian culture (synonymous with the city) and the provinces,

This is an Open Access article distributed under the terms of the Creative Commons Attribution 3.0 PL License (creativecommons.org/licenses/by/3.0/pl/), which permits redistribution, commercial and non-commercial, provided that the article is properly cited. (C) The Author(s), 2015

Publisher: Institute of Slavic Studies, Polish Academy of Sciences

Editor in chief: Jolanta Sujecka

Conception and academic editing of this issue: Maciej Falski
\end{abstract}


equated mostly with the Slavic world, which was little known in the West. The second perspective, which appeared in the second half of the eighteenth century, dealt with these relationships in the wider context of the neighbourhood of civilization and backwardness.

Keywords: Dalmatia, Enlightenment, travelogue, Morlachs, Balkans, city, provinces

Tn the early modern period, Dalmatia was an example of a culturally diversified area, in which the neighbourhood of the city and the provinces was an issue far more complex than is usually the case, because it reflected not only demographic but also political and ethnic background. Cities such as Zadar or Split were - since the Middle Ages - a part of the Venetian state, and because of that they gradually became centres of Italian culture, whose impact was also visible in the independent state of Ragusa. The Dalmatian province was the area that belonged to the Slavic world. However, it was also influenced by cultures brought by other ethnic groups, like Vlachs, and the proximity of the western border of the Ottoman Empire (Mayhew, 2008). This complexity was even more immense, when considered in historical perspective, in which Dalmatian land was a part of such states as the Roman Empire, medieval kingdoms of Serbia and Croatia, as well as Venice, the Habsburg Empire, and Ottoman Turkey. Nevertheless, in various studies on the emergence of Balkans as an idea, this specific case of Dalmatia is often neglected, being thrown to the same category as Bosnia or Macedonia. Thus, the study on the image of the Dalmatian city and its relation to the provinces in early modern period seems to be a valuable addition to those vaster issues.

It is necessary to add that the notion of neighbourhood seems to be a very promising way to describe the relation between Dalmatian urban and provincial areas. In many scientific analyses on Dalmatia, the term "frontier" is in use, because of the proximity of a triple political border (the Triplex Confinium of Austria, the Ottoman Empire and Venice). However, as specific case studies show, that Dalmatian city and provinces were bonded together (Mayhew, 2008; Wolff, 2003; Gullino, 2007) and even if they differed in many aspects (from economic to ethnic and cultural), the centuries of coexistence created a specific relationship between them, and neighbourhood would also be an appropriate word to describe this bond.

In this study, I concentrate only on the French approach to this problem, because it can be considered as representative for other Western European perspectives. The French look at the issue of neighbourhood of the city and the provinces in the area of Dalmatia is significant because it 
was characterized by a distance, which is rarely found in Venetian sources (Wolff, 2003, pp. 27-75). The French perspective was based not only on direct relations, such as travelogues and testimonies of French diplomats, but also on other documents, because the French publishers of various dictionaries and encyclopaedias were able to merge the information taken from those sources with Italian, German and English testimonies, and compile them into coherent accounts (Sajkowski, 2011). In this study, I concentrate mainly on two examples of French travel literature - Jacob Spon's travelogue from 1678, and a publication from 1802 by Louis François Cassas and Joseph Lavallée. This wide chronologic scope will allow to show changes which occurred in the French image of Dalmatia during the age of Enlightenment.

Until the second half of the $18^{\text {th }}$ century, Dalmatian cities were not frequent journey destinations, they were, nonetheless, important and frequently made stops during the journey of the French travellers, mainly members of diplomatic missions travelling to Turkey via Ragusa (and further by land to Istanbul), or sometimes by sea - in both cases they usually stopped in one of a few Dalmatian cities while sailing the Adriatic (Iorga, 1928, pp. 31, 49-52, 58, 77, 78; Samić, 1960, pp. 19-54). Thus, in the early modern period, French knowledge of the geography of the region later known as the Balkans was stronger when it came to Dalmatia and its cities. One of the first testimonies which contained extensive information about Dalmatian cities and their surrounding provinces was the travelogue of Philippe du Fresne-Canaye, who visited Dalmatia while travelling to Adrianopole as a secretary of French diplomatic mission in 1572 (Samić, 1960, pp. 29-30). But the extent of French familiarity with Dalmatian geography is attested not only by travelogues but also a publication of French geographer and sailor, Jacques Nicolas Bellin, Description géographique du golfe de Venise et de la Morée (Bellin, 1771), containing much information about Dalmatian cities, the sources of which should be associated with the growing interest of French merchants towards Dalmatia (Samić, 1960, pp. 55-56).

One of the most important travelogues that depicted Dalmatia in a very detailed way was written by Jacob Spon in the second half of the $17^{\text {th }}$ century under the title Voyage d'Italie de Dalmatie de Grece et du Levant. Spon travelled to Istanbul and further to Levant in 1775 and 1776, and the account of this travel was published for the first time in Lyon in 1678 (Brunet, 1864, p. 498). It was used as a source of information on Dalmatia in French dictionaries end encyclopaedias, for example, the information Spon provided about inhabitants of Dalmatia known under the name of Morlachs was cited in: Encyclopaedia of Diderot and D'Alambert (D’Alembert \& Diderot, 1874, p. 259), Le grand vocabulaire français, 
edited by Sébastien Chamfort (Chamfort, 1771, p. 364), Jacques Nicolas Bellin's Description géographique du golfe de Venise et de la Morée (Bellin, 1771, p. 70), Géographie moderne by Louis-Antoine Nicolle de Lacroix from 1773 (Lacroix, 1773, p. 100), and Dictionnaire géographique-portatif, from 1806 (Echard, 1806, p. 648). As late as in the beginning of the $19^{\text {th }}$ century, in the preface to the third edition of the diary on his journey to Jerusalem, François René Chateaubriand emphasised the high quality of Spon's work, and mentioned that encyclopaedists, among others, made use of it (Chateaubriand, 1826, p. CXXV). What is even more important, Jacob Spon's travelogue was used in 1802 by Joseph Lavallée, when he wrote Voyage pittoresque et historique de l'Istrie et de la Dalmatie (published 1802) - not a real travelogue, as the title suggested, but a compilation of other diaries, supplemented by the drawings (and maybe some remarks) by Louis François Cassas, who visited Istria and Dalmatia in 1782 (Caillet, 2011, pp. 924-925). Because of its importance, Spon's travelogue is an invaluable source of information about the neighbourhood of city and the provinces in Dalmatia as reflected in French literature of the early modern period.

Jacob Spon was a French connoisseur of the antiquity and it was his interest in the ancient culture that made him undertake the journey. In October 1674, the king's antiquary, Jean Vaillant, on his way to Italy visited Lyon, where Spon was living at the time. Spon joined Vaillant and travelled to Genoa, Siena and other Italian cities (Spon, 1724, pp. 1-22). In Rome, where he spent five months, describing landmarks and rewriting inscriptions, he met an English nobleman, George Wheler, who would also publish an account of his journey. It was issued in 1682, that is, five years later than Spon's (Wheler, 1682). From Rome, our French antiquarian, together with his English companion, made their way to Venetia, where they embarked on the Venetian ambassador's ship (Spon, 1724, p. 47). The stopovers on the cruise of the Adriatic Sea were at Dalmatian cities belonging to Venice. During his journey, Spon had a chance to visit, among others, Rovinj, Pula, Zadar, Trogir, Split, Solina, Klis, Jelsa and Korčula (the traveller provides Italian names of these places: Rouvigne, Pola, Zara, Traou, Spalato, Salona, Clissa, Liesina, Courzula).

In these cities, the author of the diary encountered many antique monuments, which he described thoroughly. In Pula he found, among others, the remnants of an antique amphitheatre, a temple dedicated to the deity Roma, and a construction resembling a triumphal arch (Spon, 1724, p. 49). In Zadar, the traveller found inscriptions from a Junona temple ruins and visited another amphitheatre (Spon, 1724, p. 51). The account mentions also the remnants of Trajan's aqueduct, which provided water for 
the city. In Split, the voyager encountered interesting antique landmarks on every step, but the travelogue devotes most attention to the Diocletian palace (Spon, 1724, pp. 53-62). In the visited towns, Jacob Spon came across a lot of inscriptions, which he rewrote and included in the third volume of his diaries, with French translations and commentaries.

The Dalmatia of Spon's time is, however, described by the traveller not only in the context of the abovementioned accounts of the antique landmarks. Although Jacob Spon admits in the preface that he does not want to describe the people's customs or the architecture of the visited towns, Voyage d'Italie de Dalmatie de Grece et du Levant contains also such depictions, although they are merely in the background.

As it was already said, Spon visited Dalmatian towns belonging to Venetia. The traveller was critical of Pula and Solin, but most of the cities are depicted in a positive light. Trogir he saw as a populous and prim town. He particularly liked the suburban area and the cathedral:

The town is quite nice, especially the suburban area on Bua Island. There are about four thousand people living here. The cathedral is rather good-looking [...]. It contains a few nicely made sculptures (Spon, 1724, p. 56$){ }^{1}$

He was also quite enthusiastic about the Zadar cathedral, with paintings by Titian and Tintoretto (Spon, 1724, p. 56). Spon also met a few interesting figures in this city. One of them was an archdeacon, humanist and lover of the antique, who provided Spon with the information on, among others, the Trajan aqueduct (Spon, 1724, p. 52). According to the traveller, Zadar is a beautiful city, and also one of a strategic importance. It is the site of one of the most vital Venetian citadels: "the citadel is very well fortified, with three bastions [...]" (Spon, 1724, p. 56). ${ }^{2}$

Undobtedly, for Jacob Spon, Zadar or Split were Italian cities, as he does not mention their Slavic inhabitants, he only mentions the Croats, or other Slavs, who were soldiers in the garrison of Zadar's fortress (Spon, 1724, p. 56). Another indirect information on Dalmatian Slavs is the mention about the figure of Ivan Lucić, famous historian, the author of De regno Dalmatiae et Croatiae libri sex, published in 1666, whom Spon had a chance to meet in Rome, and, as he writes, „to whom his homeland owes a lot," as to the one to describe its history (Spon, 1724, p. 56).

\footnotetext{
1 "La ville est un assez bel aspect, et principalement le faubourg qui est sur l'île de Bua. Elle peut renfermer environ quatre mille âmes. Le dôme n'est pas laid [...]. Il y a dans cette Eglise quelques statues d'assez bonne main."

2 "Une citadelle très-bien fortifiée, avec trois bastions minez et contreminez, couverts de bonnes demi-lunes et contrescarpes. [...] Aussi c'est la Capitale, \& une des meilleures places de ce que la République possède dans la Dalmatie."
} 
The city of Zara itself was portrayed as purely Roman (when it came to history) and Italian in modern times, however the case of the neighbouring provinces was different altogether. While writing about the city of Zara and its surroundings, Jacob Spon stated:

The nearby countryside is pretty well cultivated, but since Zara had skirmishes with the Turks, there are no trees left. The mountains, which are called the "Morlach Mountains," and tower along Dalmatia, are inhabited by Morlachs, who are subjects of the Republic, formerly fugitives from Albania, those people are determined and tireless, and during war want always to fight with Turks. A part of them were robbing villages, and they always returned with a loot [...]. They are of terrifying look [...]. They speak a Slavonic language and confess generally the religion of the Greek (Spon, 1724, pp. 69-70). ${ }^{3}$

This short passage was repeated in many French encyclopaedias and dictionaries, where even over a hundred years later it served as the basis for definition of the term "Morlach." It is necessary to clarify that the ethnonym Morlach comes from the "Black Vlachs" (Greek - Mavro Vlasi), and it described initially the Vlach priests and military settlers that came to Dalmatia (and other regions of the Triplex Confinium) in late Middle Ages, but gradually it came to be used (mainly by Venetians) to describe other ethnic groups (especially Slavs) who were priests, military settlers or sometimes bandits (Rapacka, 1997, p. 214). What is of importance for this study on the image of Dalmatian neighbourhood of the city and the provinces, is the fact that in the citation above this relation is described very precisely. The notion of frontier is not used in the description of the landscape surrounding the city, as it is changing gradually. Cultivated land is slowly replaced by land destroyed by hostilities, which changes further into the savage mountains inhabited by savage population.

In Jacob Spon's travelogue, Dalmatia was stretched between two poles, constituted by Italian culture, which thrived in the cities, and savage land, inhabited mainly by Slavic (or at least Slavic-speaking) population. To those two elements we can also add his historical perspective, which considers the city as built on the basis of the Roman past. In fact, while ancient Roman monuments in Dalmatia were located not only in the cities, the traveller concentrated mainly on those located in urban areas.

\footnotetext{
3 "La campagne voisine est assez bien cultivée, mais depuis que ceux de Zara ont eu des escarmouches avec les Turcs, on n'y a point laissé d'arbres. La montagne appellée la Morlaque qui regne le long de la Dalmatie est habitée des Morlaques sujets de la Republique, autrefois fugitifs d'Albanie, gens determinez \& infatigables, qui ne demandoient pas mieux pendant la guerre, que de venir aux mains avec les Turcs. Une poignée d'entreux faisait des partis pour aller saccager quelque village, et ils en revenoient toûjours chargez de butin [...]. Ils ont la mine terrible [...]. Ils parlent esclavon, et fuivent la plûpart la religion des Grecs."
} 
In Jacob's Spon travelogue we cannot find any explanation of the nature of the relationship between the city and the provinces in Dalmatia. However, in French literature the neighbourhood of Dalmatian city and province was later subjected to far-fetched interpretations. One of the brief ones, yet very significant (because of the importance of the work in which it was published) was Voltaire's statement made in Essay on the Manners and the Spirit of Nations:

How slowly, with what difficulty the humankind becomes civilized, and society perfects itself! In Venice, this gateway to Italy, where all the arts were honoured, you could see the peoples who were as little civilized as the ancient peoples of the north once were. Istria, Croatia, Dalmatia were almost barbaric: yet it was this same fertile Dalmatian \& so pleasant under the Roman empire; it was this delicious land, that Diocletian had chosen for his retirement, at a time when neither Venice nor that name existed. That is the vicissitude of human choices. The Morlachs especially were considered the fiercest people on earth (Voltaire, 1784, p. 254). ${ }^{4}$

It is obvious that by "Venice, this gateway to Italy," Voltaire could also understand Dalmatia, which was an integral part of the Venetian state. Thus, the opposition between civilisation and barbarism expressed in the abovementioned fragment could be the result of a reflection on the neighbourhood of Dalmatian city and the provinces, which is very probable, because writing about $17^{\text {th }}$-century Dalmatia, Voltaire presumably used Jacob Spon's travelogue.

Voltaire's statement, which was most probably the result of a reflection on the neighbourhood of Dalmatian city and the provinces, introduced into the image of Dalmatia a very important factor, which until today plays vital role in the image of the Balkans - the idea of progress, which appeared for the first time in the 1668 work by the French philosopher and populariser of science Bernard Fontenelle (Digression sur les anciens et les modernes), and gained popularity in French historiography in the second half of the $18^{\text {th }}$ century (Grabski, 2006, pp. 291-292). The theory of progress was used in Voltaire's Essay on the Manners of Nations to show how humanity perfects itself. However, the case of Dalmatia, in which refined Italian culture and Morlachs, who according to him were incarnation of primitive barbarity,

\footnotetext{
4 "Avec quelle lenteur, avec quelle difficulté le genre humain se civilise, et la société se perfectionne! On volait auprès de Venise, aux portes de cette Italie, où tous les arts étaient en honneur, des peuples aussi peu policés que l'étaient alors ceux du Nord. L'Istrie, la Croatie, la Dalmatie étaient presque barbares: cétait pourtant cette même Dalmatie si fertile \& si agréable fous l'empire romain; cétait cette terre délicieuse que Dioclètien avait choisie pour sa retraite, dans un temps où ni la ville de Venise ni ce nom n'existaient pas encore. Voilà quelle est la vicissitude des choses humaines. Les Morlaques surtout passaient pour les peuples les plus farouches de la terre."
} 
existed side by side with each other, proved that the rule of progress was not absolute.

The point of view visible in Voltaire's work was developed extensively in Voyage pittoresque et historique de l'Istrie et de la Dalmatie by Louis François Cassas and Joseph Lavallée. As was mentioned before, this publication from 1802 is not a real travelogue, but a compilation of other travel diaries made by the second mentioned author, to accompany the drawings of the first one (who visited Dalmatia in 1782). The travelogues used by Joseph Lavallée included those by Jacob Spon as well as Alberto Fortis (his Viaggio in Dalmazia from 1774). The work had a great number of subscribers (Cassas \& Lavallée, 1802, pp. i-vii) and was well received, especially because of the illustrations, and because French interest towards South Eastern Europe was reaching its apogee. It is probable that Napoleon himself, who in 1809 created Illyrian Provinces subjected to the French Empire, encouraged Lavallée to write the work based on Cassas's drawings (Caillet, 2011, p. 926).

Voyage pittoresque et historique de l'Istrie et de la Dalmatie was a publication in which the reader could see Dalmatian landscape in details. One of its greatest advantages was, according to Lavallée, the picturesque coexistence of wild areas with cultivated and urbanised ones (Cassas \& Lavallée, 1802, p. 2). Because Louis François Cassas was a draftsman skilled in drawing detailed antique monuments, he focused on this aspect of Dalmatian landscape, delivering to the reader the most detailed images of the Diocletian's palace in Split, the amphitheatre in Pula, and many others.

In the narrative prepared by Joseph Lavallée, the history of Dalmatia was also thoroughly explored, and most significantly for the topic at hand, the publication contained also much information on the contemporary ethnic and cultural landscape of Dalmatia, because "the people who live in surroundings of ruins are also an important object of the study" (Cassas \& Lavallée, 1802, p. i). ${ }^{5}$ In Voyage pittoresque et historique..., the urban areas were depicted as Italian and Lavallée cited extensively Jacob Spon's information about Zara which was analysed above (Cassas \& Lavallée, 1802, p. 84). The neighbourhood with the provinces, which were considered as Slavic, was interpreted in a way that elaborated on the above-mentioned observations of Voltaire. According to Joseph Lavallée, the Dalmatian population could be divided into Dalmatians and Morlachs. The first term was, according to the author, synonymous with Italians which is in itself interesting, since in $18^{\text {th }}$ century, Venetians had it refer to the Slavic population od Dalmatia (Wolff, 2003, pp. 27-75). It is possible

\footnotetext{
5 "Les peuples qui respirent autour des ruines n’offrent pas au philosophe une étude moins importante à faire."
} 
that according to Joseph Lavallée, "proper Italians" of Dalmatia are Italianspeaking inhabitants of the cities, some of whom could be of Slavic descent. The second group, the "Morlachs," were described in a manner more detailed than in Jacob Spon's account (the additional information was taken from Viaggio in Dalmatia by Alberto Fortis). Nevertheless, they were still characterised as uncivilised barbarians, or - more positively - as good savages. The nature of coexistence between those two groups was explained as follows:

This is where the two extremes met and remained present, that is to say the last Pygmies, who bore the Roman name, and the simulacrum of the first giants, who anticipated the barbarians of the north. Thus, no human force can face a power of corruption which slowly undermines morality. The long passage of centuries adds nothing to the civilization of men, whose ancestors were savages and barbarians unless a superior force acts. [...] The Morlachs are today what Slavs once were; and in Dalmatians we can find all the smallness of ancient Rome and Orient (Cassas \& Lavallée, 1802 , p. 60). ${ }^{6}$

The neighbourhood of the city, dominated by Italian culture, and the Slavic provinces was interpreted on an historical plane, in which the inhabitants of urban areas were represented as descendants of the ancient Romans (both western and eastern ones), but they personified the decadence of the empire. This conclusion was a perfect complement to Louis François Cassas's illustrations, where most of the Roman ruins scattered throughout Dalmatia were drawn in, or in close proximity to, the cities (McCallam, 2011, p. 134), which by that means became the witnesses to Roman decadence and the invasions of barbarians. The latter remained in Dalmatia under the name of Morlachs, who preserved the barbaric manners of their Slavic ancestors. The opinion about the barbarity and backwardness of Southern Slavs was already an idea that was described in detail in French literature, for example by Claude-Charles de Peyssonnel in 1765 (Observations historiques et géographiques sur les peuples barbares...). Lavallée's theory that both "nations" inhabiting Dalmatia were lasting in a frozen scheme from the times of decadence of the Roman Empire was, however, a novelty. We can easily explain this development - when in second half of $17^{\text {th }}$ century Jacob Spon described the Italian culture in Dalmatia, the economy

\footnotetext{
6 "C’est ici que deux extrêmes se sont rencontrés et sont restés en présence, c’est-à-dire les derniers Pygmées qui porterent le nom romain, et le simulacre des premiers géants qui annoncerent les barbares du nord. Ainsi donc nulle force humaine ne peut relever une puissance que la corruption des moeurs a lentement minée. Ainsi le long passage des siecles najoute rien à la civilisation des hommes dont les aïeux furent sauvages et barbares, quand il ne sont pas appuyés par par une force majeure. [...] Les Morlaques sont aujord'hui que furent les Slaves; et dans les Dalmatiens on retrouve encore toutes les petitesses des cours et d'Orient et de Rome."
} 
and political power of countries of the Apennine Peninsula was weakening, yet Venice was still an important participant in European politics. In 1802, when Joseph Lavallée published Voyage pittoresque et historique de l'Istrie et de la Dalmatie, it had been just five years since the Republic of Venice ceased to exist after than a millennium of statehood. Lavallée was thus compelled to write not only about the barbarity of Dalmatian Slavs, but also about the decadence of "Italian" Dalmatia.

Concluding, we can summarize that French image of the neighbourhood of the city and the provinces in Dalmatia in the early modern period featured two different perspectives. The first related to the neighbourhood of the sophisticated Italian culture (synonymous with the city) and the provinces, which were associated mostly with the Slavic world, little known in the West. The other perspective, which appeared in the second half of the eighteenth century, dealt with these relationships in the wider context of the neighbourhood of civilization and backwardness that combined reflection on the Italian-Slavic relations with the historical reflection on the proximity of the Roman civilization (whose monuments were preserved in Dalmatian cities) with barbarism - which led to its end. This perspective was visible in Essay on the Manners and the Spirit of Nations by Voltaire, who was surprised that Italian culture had not - in his opinion - fulfilled its civilizing role in relation to the Slavs, and in Lavallée's and Cassas's work, which developed this point of view extensively. It is necessary to emphasise that the second perspective (which in fact is an elaboration of the first one) became, and is to this day, an important constituent of the image of the Balkans.

\section{References}

Alembert, J. d', \& Diderot, D. (Eds.). (1874). Encyclopédie, ou Dictionnaire raisonné des sciences, des arts et des métiers par une société des gens de lettres: Tome vingtdeuxieme (Vol. 22). Berne: Société Typographique [First publication 1780].

Bellin, J. N. (1771). Description géographique du golfe de Venise et de la Morée: Avec des remarques pour la navigation, \& des cartes \& plans des côtes, villes, ports \& mouillages. Paris: Didot.

Brunet, J-C. (1864). Manuel du libraire et de l'amateur de livres. Paris: Didot.

Cassas, L. F., \& Lavallée, J. (1802). Voyage pittoresque et historique de l'Istrie et de la Dalmatie. Paris: Didot.

Caillet, J-P. (2011). La publication du « Voyage pittoresque et historique de l'Istrie et de la. Dalmatie » de L.-F. Cassas et J. Lavallée dans le contexte de la politique napoléonienne en Illyrie. Kačić, 41-43, 919-927.

Chamfort, S. (Ed.). (1771). Le grand vocabulaire français: Tome dux-huitième (Vol. 18). Paris: Guyot.

Chateaubriand, F-R. (1826), Euvres complètes de M. le vicomte de Chateaubriand: Tome VIII (Vol. 8). Paris. 
Echard, L. (Ed.). (1806). Dictionnaire géographique-portatif. Paris: Delelain fils.

Grabski, A. (2006). Dzieje historiografii. Poznań: Wydawnictwo Poznańskie.

Gullino, G. (2007). Different' peoples of the East Adriatic: The point of view of the Venetian patricians (18th century). In E. Ivetić \& D. Roksandić (Eds.), Tolerance and intolerance in Triplex Continuum: Approaching the «other» on the borderlands Eastern Adriatic and beyond 1500-1800 (pp. 153-161). Padova: Cleup.

Iorga, N. (1928). Les voyageurs français dans l'Orient européen. Paris: Sorbonne.

Mayhew, T. (2008). Dalmatia between Ottoman and Venetian rule: Contado Di Zara, 1645-1718. Roma: Viella.

La Croix, L-A. N. de (Ed.). (1786). Géographie moderne (vol. 2). Paris: Delalain.

McCallam, D. (2011). (Ac)claiming Illyria: Eighteenth-century Istria and Dalmatia in Fortis, Cassas, and Lavallée. Central Europe, 9(2), 125-141. http://doi.org/10.117 9/147909611X13164249562937

Rapacka, J. (1997). Leksykon tradycji chorwackich. Warszawa: Slawistyczny Ośrodek Wydawniczy.

Sajkowski, W. (2011). Morlacy w zachodnioeuropejskiej literaturze encyklopedycznej XVIII i XIX wieku: Recepcja dzieła Alberto Fortisa Viaggio in Dalmazia. In J. Paszkiewicz \& Z. Pentek (Eds.), Stereotypy bałkańskie: Księga jubileuszowa profesor Ilony Czamańskiej (pp. 131-143). Poznań: Instytut Historii.

Samić, M. (1960). Les voyageurs français en Bosnie à la fin du XVIIIe siècle et au début $d u$ XIXe et le pays tel qu'ils l'ont vu. Paris: Didier.

Spon, J. (1724). Voyage d'Italie de Dalmatie de Grece et du Levant: Tome premier (Vol. 1). La Haye: Rutgert Albertis.

Voltaire. (1784). Essai sur les mours et l'esprit de nations et les principaux faits de l'histoire depuis Charlemagne jusqu'au Louis XIII. Berne: Imprimerie de la Société littéraire-typographique.

Wheler, G. (1682). A journey into Greece, by George Wheler Esq; in company of Dr. Spon of Lyon. London: Papillon.

Wolff, L. (2003). Venice and the Slavs of Dalmatia: The drama of the Adriatic Empire in the Venetian Enlightenment. Stanford: Stanford University Press.

\section{Note}

No conflicts of interest exists.

This work was supported by a grant from National Science Centre, Poland (2014/13/D/HS3/03701). 